\title{
Effect of rate and method of phosphorus application on the growth and development of 'Pasja' crops
}

\author{
E. CHAKWIZIRA ${ }^{1 *}$, D.J. MOOT ${ }^{1}$, W.R. SCOTT ${ }^{1}$ and A. FLETCHER ${ }^{2}$ \\ ${ }^{1}$ Department of Agriculture and Life Sciences, Lincoln University, P.O. Box 7646, Canterbury \\ ${ }^{2}$ New Zealand Institute of Plant and Food Research Limited, 74 Gerald Street, Lincoln \\ * Current address: The New Zealand Institute for Plant \& Food Research Limited \\ Emmanuel.Chakwizira@plantandfood.co.nz
}

\begin{abstract}
'Pasja' (Brassica campestris $\mathrm{x}$ napus) was grown at Lincoln in 2008, with banded or broadcast phosphorus (P) fertiliser applied at $0,20,40$ or $60 \mathrm{~kg} / \mathrm{ha}$ at establishment on a Templeton silt loam soil of moderate fertility (Olsen P of 9-17 mg/ kg range for individual plots). Total dry matter (DM) production, leaf to stem ratios and leaf area development were measured over time and related to the biophysical environment. Final $\mathrm{DM}$ yield increased with $\mathrm{P}$ rate from $3,730 \mathrm{~kg} \mathrm{DM} / \mathrm{ha}$ for the control to $\sim 5,000 \mathrm{~kg} \mathrm{DM} / \mathrm{ha}$ at $60 \mathrm{~kg} \mathrm{P} / \mathrm{ha}$. The leaf to stem ratio declined from between 22 and 31 at 17 days after emergence to 10.3 at the final harvest. Leaf area index (LAI) for the control crops was lower than for those that received $\mathrm{P}$ fertiliser, but there were no differences among the $\mathrm{P}$ fertilised crops. Total accumulated intercepted solar radiation $\left(\mathrm{RI}_{\text {cum }}\right)$ was $8 \%$ greater when $\mathrm{P}$ was applied compared with the control. This difference was the main contributor to differences in total dry matter yield and was independent of the application method.
\end{abstract}

Keywords: Brassica campestris, critical leaf area index, DM accumulation, leaf area index, leaf to stem ratio, solar radiation

\section{Introduction}

Forage brassica crops are grown in diverse climates and soil fertility situations (Wilson et al. 2006). This makes it difficult to specify a single optimum fertiliser rate. Brassica crops have been shown to respond to fertiliser applications, especially phosphorus (P) (Wilson et al. 2006) when Olsen P levels are less than $15 \mathrm{mg} / \mathrm{kg}$ soil (White et al. 1999).

Phosphorus deficiency can lead to early senescence of older leaves and stunting of new leaves (Moot et al. 2007), resulting in reduced leaf dry matter (DM) yield. Furthermore, adequate $\mathrm{P}$ nutrition during the establishment phase has been shown to improve subsequent crop performance (Grant et al. 2000) and hence current recommendations are to apply all $\mathrm{P}$ fertiliser at sowing. Wilson et al. (2006) indicated that 'Pasja' crops utilise banded $P$ fertiliser seven times more effectively than broadcast fertiliser P. However, most of their reported $\mathrm{P}$ responses were on soils of low
$\mathrm{P}$ status (Olsen $\mathrm{P}<10)$ while most agricultural soils in New Zealand have P levels higher than this. It is also unclear how banded or broadcast $\mathrm{P}$ affects crops at higher P levels.

Phosphorus is a major farm cost, accounting for about $20 \%$ of the expenditure on lowland dairy farms (Moot et al. 2007). Phosphorus is also highly immobile in soils and rapidly fixes on to soil surfaces (McLaren \& Cameron 1996). Too much fertiliser P increases the risk of environmental damage caused by P runoff and is a high cost. Thus, an understanding of optimum application rates, timing and placement of $P$ fertilisers (Lewis 1941) is desirable.

The objective of this experiment was to determine the effect of $0,20,40$, or $60 \mathrm{~kg} \mathrm{P} / \mathrm{ha}$ either banded or broadcast at sowing on the growth and development of 'Pasja' forage crops.

\section{Materials and Methods}

The experiment was situated at the New Zealand Institute for Plant \& Food Research Limited, Canterbury (latitude 4339', altitude $14 \mathrm{~m}$ ) which has a long-term average rainfall of $640 \mathrm{~mm}$.

The $2 \times 4$ factorial design was a randomised complete block with three replicates. Triple superphosphate at 0 , 20,40 or $60 \mathrm{~kg} \mathrm{P} / \mathrm{ha}$ was either hand broadcast before sowing or banded below the seed with an Өyjord drill.

The site was situated on a deep, moderately drained Templeton silt loam soil (Webb et al. 2000; McLaren \& Cameron 1996), classified as a Pallic soil (Typic immature), soil taxonomy; Udic or Typic Haplustepts. A soil test to $150 \mathrm{~mm}$ depth was taken from all 24 plots; which were approximately $30 \mathrm{~m}^{2}$ each. The average Quick test results before sowing were: $\mathrm{pH}$ 6.1, Olsen P 13.3 (9-17), K 7, Ca 9.5. Available soil $\mathrm{N}$ determined by anaerobic incubation was low at $76 \mathrm{~kg} / \mathrm{ha}$.

Soil preparation involved conventional cultivation after deep ploughing. Viable seed at $4 \mathrm{~kg} / \mathrm{ha}$ was drilled in $150 \mathrm{~mm}$ rows at $\sim 20 \mathrm{~mm}$ depth. Nitrogen (as urea) at $100 \mathrm{~kg} / \mathrm{ha}$ was applied 3 weeks after emergence. Seeds were treated with 'Superstrike ${ }^{\circledR}$ ' to guard against springtails (Bourletiella spp.) and fungal infections (Salmon \& Dumbleton 2006). Some damage due to leaf miner maggot (Liriomyza brassicae) was observed 6 weeks 
Table 1 Dry matter yield $(\mathrm{kg} / \mathrm{ha})$ and leaf to stem ratio on the last day of harvest $\left(20^{\text {th }}\right.$ of March) for 'Pasja' sown with different methods of application and rates of phosphorus at Lincoln in 2008.

\begin{tabular}{|c|c|c|c|c|}
\hline \multirow{2}{*}{$\frac{\text { Phosphorus }}{\text { Method (M) }}$} & \multicolumn{2}{|c|}{ Leaf: Stem ratio } & \multicolumn{2}{|c|}{ Yield (kg /ha) Total } \\
\hline & $\mathrm{Ba}^{1}$ & $\mathrm{Br}$ & $\mathrm{Ba}$ & $\mathrm{Br}$ \\
\hline & 11.0 & 10.1 & 4370 & 4420 \\
\hline Significance & \multicolumn{2}{|c|}{$\mathrm{NS}^{2}$} & \multicolumn{2}{|c|}{ NS } \\
\hline \multicolumn{5}{|l|}{ Rate (R) (kg P/ ha) } \\
\hline 0 & 10.6 & 10.6 & 3730 & 3730 \\
\hline 20 & 10.6 & 10.4 & 4390 & 4440 \\
\hline 40 & 11.3 & 10.0 & 4320 & 4610 \\
\hline 60 & 11.3 & 9.78 & 5080 & 4870 \\
\hline $\mathrm{LSD}_{5 \%}$ & \multicolumn{2}{|c|}{2.1} & \multicolumn{2}{|c|}{726} \\
\hline Significance & \multicolumn{2}{|c|}{ NS } & \multicolumn{2}{|c|}{ * } \\
\hline Interaction $\mathrm{M}^{*} \mathrm{R}$ & \multicolumn{2}{|c|}{$P=0.086$} & \multicolumn{2}{|c|}{ NS } \\
\hline CV (\%) & \multicolumn{2}{|c|}{13.5} & \multicolumn{2}{|c|}{9.4} \\
\hline
\end{tabular}

${ }^{1} \mathrm{Ba}=$ Banding \& $\mathrm{Br}=$ Broadcast

${ }^{2} \mathrm{NS}=$ Not significant

Table 2 Weighted mean absolute growth rate (WMAGR), maximum crop growth rate $\left(C_{m a x}\right)$, time to reach $50 \%$ of total dry matter (M) and duration of exponential growth phase (DUR) for Pasja sown with different methods of application and rates of phosphorus at Lincoln in 2008.

\begin{tabular}{|c|c|c|c|c|}
\hline Phosphorus & $\begin{array}{c}M \\
\text { (days) }\end{array}$ & $\begin{array}{l}\text { DUR } \\
\text { (days) }\end{array}$ & $\begin{array}{l}\text { WMAGR } \\
\left(\mathrm{g} / \mathrm{m}^{2} / \text { day }\right)\end{array}$ & $\begin{array}{c}\mathrm{C}_{\max } \\
\left(\mathrm{g} / \mathrm{m}^{2} / \text { day }\right)\end{array}$ \\
\hline \multicolumn{5}{|l|}{ Method } \\
\hline Banding & 35 & 44 & 11.5 & 17.9 \\
\hline Broadcast & 35 & 48 & 10.2 & 15.0 \\
\hline LSD $_{5 \%}$ & 6 & 10 & 1.26 & 1.86 \\
\hline Significance & $\mathrm{NS}^{1}$ & NS & * & * \\
\hline \multicolumn{5}{|l|}{ Rate (kg P/ha) } \\
\hline 0 & 32 & 43 & 8.97 & 13.20 \\
\hline 20 & 36 & 48 & 9.99 & 14.69 \\
\hline 40 & 34 & 44 & 11.8 & 17.40 \\
\hline 60 & 39 & 49 & 12.4 & 18.40 \\
\hline $\mathrm{LSD}_{5 \%}$ & 8 & 14 & 1.79 & 2.63 \\
\hline Significance & NS & NS & * & * \\
\hline Method * Rate & NS & NS & NS & NS \\
\hline CV(\%) & 18.4 & 24.3 & 13.3 & 16 \\
\hline
\end{tabular}

${ }^{1} \mathrm{NS}=$ Not significant; ${ }^{*}=\mathrm{P}<0.05$
Figure 1 Pasja dry matter (DM) accumulation over 73 days after emergence at $0(\bullet) ; 20(\nabla) ; 40(\bullet)$ or $60 \mathrm{~kg}$ $\mathrm{P} /$ ha $(\diamond)$. Bars represent LSD at $5 \%$ level. (See Table 2 for variables derived from the fitted logistic curves). Solid lines ( $\square$ ) represent quadrat $\left(0.5 \mathrm{~m}^{2}\right)$ sampling and dashed lines (----) represent whole seedling sampling.

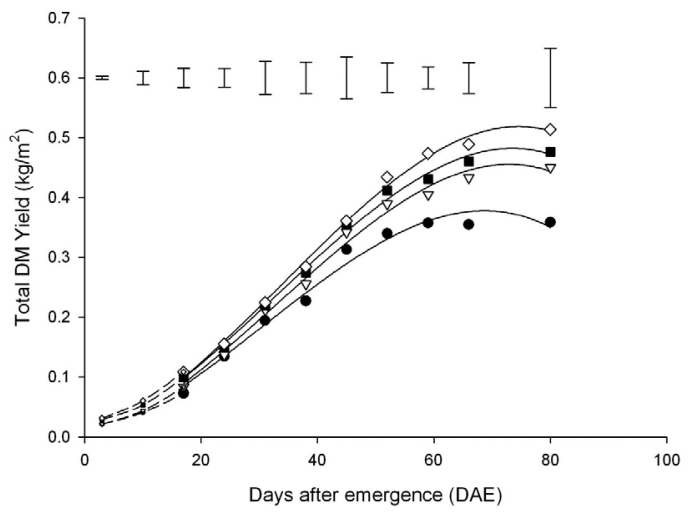

Figure 2 Pasja leaf area index accumulation over 66 days, at $0(\bullet) ; 20(0) ; 40(\nabla)$ or $60 \mathrm{~kg} \mathrm{P} / \mathrm{ha}(\nabla)$. Bars are LSD at $5 \%$ level (See Table 3 for variables derived from the fitted logistic curves). Solid lines (ロ) represent quadrat $\left(0.5 \mathrm{~m}^{2}\right)$ sampling and dotted lines (…) represent whole seedling sampling.

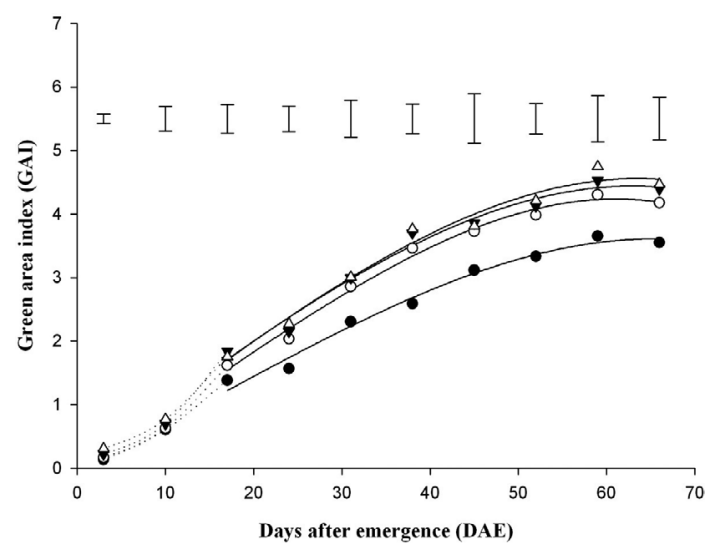

after emergence. Additional insecticides and herbicides were applied as required throughout the experiment.

\section{Measurements}

\section{DM accumulation and leaf and stem partitioning}

An initial DM harvest of all seedlings in a $30 \mathrm{~cm}$ row was made at 3 and 10 days after emergence (DAE) and portioned into shoot and root components. Thereafter, DM was measured every 7 days from destructive harvests of $0.5 \mathrm{~m}^{2}$ quadrats to ground level. The final harvest was at 73 DAE. For all harvests samples were 
Table 3 Weighted mean absolute leaf area expansion rate (LAER), maximum leaf area index (max LAI), maximum leaf area expansion rate $\left(\mathrm{C}_{\max }\right)$, time to reach $50 \%$ of max LAI (M) and duration of exponential leaf area expansion phase (DUR) for Pasja sown with four rates of phosphorus at Lincoln in 2008.

\begin{tabular}{llllll}
\hline Phosphorus & $\max$ LAI & M & DUR & LAER & $\mathrm{C}_{\max }$ \\
& $\left(\mathrm{cm}^{2} / \mathrm{m}^{2}\right)^{A}$ & (days) & $($ days $)$ & $\left(\mathrm{cm}^{2} / \mathrm{m}^{2} /\right.$ day $)$ & $\left(\mathrm{cm}^{2} / \mathrm{m}^{2} /\right.$ day $)$ \\
\hline
\end{tabular}

Rate of $\mathrm{P}(\mathrm{kg} \mathrm{P} / \mathrm{ha})$

\begin{tabular}{lccccc}
0 & 3.56 & 25 & 46 & 0.08 & 0.11 \\
20 & 4.61 & 28 & 38 & 0.13 & 0.20 \\
40 & 4.83 & 26 & 48 & 0.13 & 0.18 \\
60 & 4.96 & 29 & 44 & 0.15 & 0.21 \\
LSD $_{5 \%}$ & 0.7 & 5.41 & 25 & 0.05 & 0.07 \\
Significance & $*$ & $\mathrm{NS}^{1}$ & $\mathrm{NS}$ & $*$ & $*$ \\
CV(\%) & 13.3 & 16.2 & 46.0 & 35.2 & 34.6 \\
\hline
\end{tabular}

${ }^{1} \mathrm{NS}=$ Not significant; ${ }^{*}=\mathrm{P}<0.05$

AUnits are $\mathrm{cm}^{2}$ leaf area $/ \mathrm{m}^{2}$ soil area.

gently washed and then dried in a forced-air oven at $70^{\circ} \mathrm{C}$ to constant weight. Representative 10 plant subsamples were retained to measure leaf and stem DM.

A functional growth analysis used a Maximum Likelihood Programme (Ross et al. 1987) and fitted generalised logistic curves to describe DM accumulation and leaf area index (Gallagher \& Robson 1984). The weighted mean absolute growth rate (WMAGR - the mean growth rate over the period when crop accumulated most of its DM), duration of exponential growth (DUR - duration of crop growth over which most growth occurred) and maximum crop growth rate $\left(\mathrm{C}_{\max }\right)$ were derived as described by Anwar et al. (2003).

\section{Canopy development and radiation interception}

Percentage light transmissions through the canopy and leaf area index (LAI) were measured at 6 to 14 and 7-day intervals, respectively. Light interception was measured with a ceptometer. Leaf area was measured with an Area meter- model LI-3100 in $\mathrm{cm}^{2}$ and converted into an LAI. Light measurements were stopped once the critical LAI $\left(\right.$ LAI $\left._{\text {crit }}\right)$ was attained, which was defined as LAI at which $95 \%$ of the incoming radiation was intercepted.

Intercepted photosynthetically active radiation (PAR) was calculated at 0.5 times the total intercepted radiation. The proportion of radiation intercepted by the canopy was calculated as described by Yunusa et al. (1993). Accumulated solar radiation $\left(\mathrm{RI}_{\mathrm{cum}}\right)$ for the season was calculated as the sum of interpolated daily
Table 4 Leaf area index (LAl), interception of radiation (RI) and accumulated intercepted radiation $\left(\mathrm{RI}_{\text {cum }}\right)$ for Pasja, 38 and 59 days after emergence when sown with different methods of application and rates of phosphorus at Lincoln in 2008.

\begin{tabular}{|c|c|c|c|c|c|c|}
\hline \multirow[b]{3}{*}{ Phosphorus } & \multicolumn{6}{|c|}{ Number of days after emergence (DAE) $)^{1}$} \\
\hline & \multicolumn{3}{|c|}{38} & \multicolumn{3}{|c|}{59} \\
\hline & $\mathrm{LAl}^{\mathrm{A}}$ & RI (\%) & $\mathrm{RI}_{\text {cum }}^{\mathrm{B}}$ & LAl & $\mathrm{RI}(\%)$ & $\mathrm{RI}_{\text {cum }}$ \\
\hline \multicolumn{7}{|c|}{ Rate of $\mathrm{P}(\mathrm{kg} \mathrm{P} / \mathrm{ha})$} \\
\hline 0 & 2.59 & 90.7 & 236.2 & 3.85 & 95.3 & 383.4 \\
\hline 20 & 3.46 & 93.0 & 254.6 & 4.90 & 97.5 & 406.1 \\
\hline 40 & 3.80 & 94.9 & 263.0 & 4.93 & 96.9 & 413.4 \\
\hline 60 & 3.87 & 95.5 & 266.7 & 4.95 & 96.5 & 418.2 \\
\hline $\mathrm{LSD}_{5 \%}$ & 0.66 & 2.00 & 21.5 & 1.04 & 3.2 & 22.6 \\
\hline Significance & * & * & * & * & $\mathrm{NS}^{2}$ & * \\
\hline CV(\%) & 11.1 & 1.5 & 4.8 & 13.7 & 1.9 & 3.2 \\
\hline
\end{tabular}

$138 \mathrm{DAE}$ was the last measurement before the impact of $\mathrm{P}$ on total DM became apparent (Fig. 1) and 59 DAE was when the control crops attained $\mathrm{LAl}$,

${ }^{2} \mathrm{NS}=$ Not significant; ${ }^{*}=\mathrm{P}<0.05$

${ }^{\mathrm{A}} \mathrm{LAI} \mathrm{crit}=3.8 ;{ }^{\mathrm{B}}$ Accumulated intercepted radiation $\left(\mathrm{MJ} / \mathrm{m}^{2}\right)$

radiation interception (RI) for the duration of the crop.

\section{Meteorological conditions}

A summary of meteorological data taken from the Broadfield weather station (located $\sim 50 \mathrm{~m}$ from the experiment site) showed below average rainfall, with a total deficit of $220 \mathrm{~mm}$ over the experimental period. A total of $105 \mathrm{~mm}$ of water was added as irrigation; $75 \mathrm{~mm}$ in January when total rainfall was $30 \%$ of long term average of $50 \mathrm{~mm}$ and $30 \mathrm{~mm}$ in the first week of February. Over the crop growth period there were 20 ground frosts. The highest daily temperature recorded was $32.7^{\circ} \mathrm{C}$ on 12 January 2008 and the lowest daily temperature was $1.9^{\circ} \mathrm{C}$ on $4 \mathrm{March}$. The highest daily rainfall $(62.4 \mathrm{~mm})$ was recorded on 15 February.

\section{Data analysis}

Intercepted PAR, leaf area development and all dry matter yields were analysed using analysis of variance (ANOVA). Significant interactions and main effects were separated by least significant difference $\left(\mathrm{LSD}_{5 \%}\right)$. All analyses were performed using Genstat version 10 statistical package.

There was a wide variation in the Olsen P levels among the plots. However, an analysis with the Olsen $\mathrm{P}$ as a covariate did not show a significant effect. Based on this result, analyses used the rate of $\mathrm{P}$ applied as the independent variable. 


\section{Results}

Dry matter (DM) yield

At the final harvest, yield was unaffected by $\mathrm{P}$ application method but increased with $P$ rate from 3,730 $\mathrm{kg} \mathrm{DM} / \mathrm{ha}$ for the control ( $0 \mathrm{~kg} \mathrm{P} / \mathrm{ha})$ to $\sim 5,000 \mathrm{~kg} \mathrm{DM} /$ ha at $60 \mathrm{~kg} \mathrm{P} /$ ha (Table 1). A breakdown of total DM showed that leaf to stem ratio ranged from 9.78 to 11.30 for the broadcast and banded treatments with $60 \mathrm{~kg} \mathrm{P} /$ ha, respectively. The DM yield was essentially made up of the leaf, accounting for more than $90 \%$.

There was a suggestion of an interaction $(\mathrm{P}=0.086)$ between method of application and rate of $\mathrm{P}$ with the ratio increasing with $\mathrm{P}$ level for the banded treatments but decreasing with the broadcast.

\section{DM accumulation over time}

The pattern of DM accumulation through the season differed $(\mathrm{P}<0.05)$ with the rate of $\mathrm{P}$ applied (Fig. 1), between the control and those that received $\mathrm{P}$ fertiliser, but was unaffected by the method of application.

Fig. 1 also shows that shoot DM accumulation of the seedlings over 17 DAE was consistent with that from the later quadrat harvests. Yields did not differ among fertiliser rates until $44 \mathrm{DAE}$, after which the impact of different $\mathrm{P}$ rates was more apparent but not statistically different. There was no difference in crop $\mathrm{DM}$ accumulation among the three $\mathrm{P}$ application rates relative to the control.

Both the WMAGR and $\mathrm{C}_{\text {max }}$ responded to the method of application and rate of $\mathrm{P}$ but there was no interaction (Table 2). The WMAGR increased to $11.5 \mathrm{~g} / \mathrm{m}^{2} /$ day when $\mathrm{P}$ was banded compared with broadcast (10.2), which translates to $13 \mathrm{~kg} / \mathrm{ha} /$ day. WMAGR was $32 \%$ higher at $40 \mathrm{~kg} \mathrm{P} /$ ha than the control. The $\mathrm{C}_{\max }$ increased by $19 \%$ to $17.9 \mathrm{~g} / \mathrm{m}^{2}$ per day for banding over broadcast ( $\sim 29 \mathrm{~kg} / \mathrm{ha} /$ day) and $33 \%$ from the control to the $40 \mathrm{~kg}$ $\mathrm{P} /$ ha crops. However, these responses of both WMAGR and $\mathrm{C}_{\text {max }}$ to the method of application were not reflected in the final DM yields (Table 1).

Leaf area index (LAI) and solar radiation interception (RI)

As expected, LAI increased during the growing season and differed $(\mathrm{P}<0.05)$ with the application of $\mathrm{P}$ from 38 DAE (Fig. 2). The increase in LAI was most rapid during the first 38 DAE for all the treatments.

Fig. 2 also shows that canopy development for 'Pasja' seedlings over 17 DAE was reasonably consistent with that from quadrat harvests. Leaf area index for the control was consistently lower than the fertiliser treatments, but there was no difference in the pattern of LAI accumulation among the crops sown with higher rates of $P$.

Table 3 shows that the LAER, max LAI and $\mathrm{C}_{\max }$ over the exponential leaf area expansion period increased with $\mathrm{P}$ fertiliser application but were unaffected by the method of $\mathrm{P}$ application. The LAER increased by $71 \%$ to $\sim 0.14 \mathrm{~cm}^{2} / \mathrm{m}^{2} /$ day and $\mathrm{C}_{\max }$ increased by $79 \%$ to $0.20 \mathrm{~cm}^{2} / \mathrm{m}^{2} /$ day when $\mathrm{P}$ was applied compared with the control. The max LAI for the control crops of 3.56 was $35 \%$ less than the mean of all $\mathrm{P}$ treatments.

\section{Radiation interception (RI)}

The relationship between RI and LAI was asymptotic with no treatment effect (data not shown) with a critical LAI $\left(\mathrm{LAI}_{\text {crit }}\right.$ ) of $\sim 3.8$.

Leaf area index, percentage radiation interception (RI) and accumulated intercepted radiation ( $\mathbf{R I}_{\text {cum }}$ ) The total $\mathrm{RI}_{\text {cum }}$ was $8 \%$ greater when $\mathrm{P}$ was applied (mean of all $\mathrm{P}$ rates) compared with the control at 59 DAE (Table 4) when the crop had attained LAI ${ }_{\text {crit }}$.

Table 4 also shows that LAI, RI and RI cum did not respond to the method of $\mathrm{P}$ application at 38 or $59 \mathrm{DAE}$, but were affected by the rate of P. The LAI and $\mathrm{RI}_{\text {cum }}$ at 38 DAE showed no differences among higher rates of P. However, the RI indicates that only the $60 \mathrm{~kg} \mathrm{P} / \mathrm{ha}$ treatment had attained $\mathrm{LAI}_{\text {crit }}$ at that time.

\section{Discussion}

\section{Herbage DM yield}

DM yields did not respond to the method of $\mathrm{P}$ application (Table 1). These results are in contrast to reports in the literature (Wilson et al. 2006) that suggested banding of P fertilisers increased 'Pasja' DM yield. This could be a result of the difference in initial Olsen $\mathrm{P}$ levels for the experimental sites, which were $13.3 \mathrm{mg} / \mathrm{kg}$ in this experiment compared with $6 \mathrm{mg} / \mathrm{kg}$ of soil.

The differences in DM accumulation of control and $P$ fertilised treatments over the growing season (Fig. 1) were attributed to higher WMAGR for the P fertiliser treatments during the exponential growth phase (Table 2) since there were no differences in the duration of the growth phase. The WMAGR and consequently $\mathrm{C}_{\max }$ responded to the method of $\mathrm{P}$ application (Table 2 ), but this did not translate into differences in final yield (Table 1). This response to $P$ fertiliser may be a result of more $\mathrm{P}$ being available to the crop as the rate of application was increased.

At the final harvest, maximum yield was obtained at $40 \mathrm{~kg} \mathrm{P} / \mathrm{ha}$ for both methods of application (Table 1). This was unexpected as Grant et al. (2000) reported that $\mathrm{P}$ was easily accessible to roots when banded beneath the seed rather than broadcast throughout the soil. However, the optimum P level (40 kg P/ha) is similar to the $50 \mathrm{~kg} \mathrm{P} / \mathrm{ha}$ reported by Wilson et al. (2006). Surprisingly, this was not affected by the initial Olsen $P$ level, which suggests that the application of fertiliser $P$ at establishment was more important than the actual soil P levels of 9-17 mg/kg of soil used in this experiment. The implication is that even at moderate $\mathrm{P}$ levels 
seedlings may be P deficient until they have sufficient root volume to meet crop demand.

The high leaf to stem ratio $(9.78-11.3)$ is an indication that 'Pasja' DM was essentially made up of the leaf. The stem is represented by a 'crown' and remained less than $50 \mathrm{~g} / \mathrm{m}^{2}$ throughout the experiment, compared with the $\sim 80 \mathrm{~g} / \mathrm{m}^{2}$ reported by Wilson et al. (2006).

\section{LAI and radiation interception (RI)}

Both LAI (Fig. 2) and RI (Table 4) increased with P application. This is consistent with observations on maize (Zea mays) grown under P-deficient soils (Plenet et al. 2000; Fletcher et al. 2008) where LAI and RI for the control treatments were consistently lower than P fertiliser treatments at Olsen P levels of 6-7 mg/ $\mathrm{kg}$. Reduced LAI for the control can be attributed to reduced leaf area expansion rates and smaller final leaf area per leaf (Tables 3 and 4). Differences in LAI could also be attributed to a higher LAER for the fertiliser $P$ treatments during the exponential leaf area expansion phase (Table 3) rather than to any difference in the duration of the exponential phase. Differences in LAI were more evident as the season progressed (Fig. 2), which may coincide with a shift from root growth priority to shoot growth. The effects of P deficiency on LAER and maximum LAI are also consistent with observation made on other dicotyledonous $\mathrm{C}_{3}$ crop species: common bean (Phaseolus vulgaris L) (Lynch et al. 1991) and sunflower (Helianthus annuus L.) (Rodriguez et al. 1998).

The RI for the control was lower than those receiving $P$ fertiliser early in the season (Table 4), but there were no differences by the end of the season. The deficit in RI for the control crop may be ascribed mainly to the early delay in the leaf area expansion process. This resulted in a lower LAI on each day and hence a reduced green surface area to intercept radiation early in the season. This is particularly important before LAI $_{\text {crit }}$ is attained and when radiation receipts are highest. This also agrees with findings by Plenet et al. (2000) for maize.

Neither the method of application nor the rate of $\mathrm{P}$ affected the relationship between RI and LAI. The $\mathrm{LAI}_{\text {crit }}$ of 3.8 is within the range reported in literature (Hay \& Porter 2006) of 3-5. The $40 \mathrm{~kg} \mathrm{P} / \mathrm{ha}$ crop attained $\mathrm{LAI}_{\text {crit }} \sim 21$ days earlier than the control (Fig. 2, Table 4), which translated into an extra $149 \mathrm{MJ} \mathrm{PAR} / \mathrm{m}^{2}$. This was probably the main physiological process that contributed to the difference in final DM yield (Table 1). Effectively the differences in leaf area expansion and hence time to $\mathrm{LAI}_{\text {crit }}$ affected DM production because of their impact on the interception of solar radiation, rather than any change in light use efficiency.

\section{Conclusions}

$\mathrm{P}$ response was even at Olsen $\mathrm{P}$ range of $9-17 \mathrm{mg} / \mathrm{kg}$ soil which means the application of fertiliser $\mathrm{P}$ at establishment was more important than actual soil P levels.

The maximum DM yield was attained at $40 \mathrm{~kg} \mathrm{P} / \mathrm{ha}$ for both methods of $\mathrm{P}$ application, as the $60 \mathrm{~kg} \mathrm{P} / \mathrm{ha}$ was not significantly different in yield. It is therefore proposed that farmers apply a maximum of $40 \mathrm{~kg} \mathrm{P} /$ ha when growing 'Pasja' forage crops under conditions similar to this experiment.

Method of $\mathrm{P}$ application showed no significant difference in final yield.

Control crops had low maximum LAI (3.6) compared with 4.9 for the $60 \mathrm{~kg} \mathrm{P} /$ ha crops and intercepted $\sim 149$ $\mathrm{MJ} / \mathrm{m}^{2}$ less solar radiation than fertilised crops.

The differences in DM yield associated with $\mathrm{P}$ fertiliser were therefore attributed to the changes in $\mathrm{RI}_{\text {cun }}$

It is proposed that $\mathrm{P}$ fertiliser/fertility should be adequate at establishment to enhance leaf expansion, allowing the crop to achieve LAI $_{\text {crit }}$ earlier. This is important as it lengthens the period under full cover and hence light interception resulting in more DM.

\section{ACKNOWLEDGEMENTS}

'Pastoral 21' program (contract number C10X0604; Objective 3) for financial assistance to E. Chakwizira, the New Zealand Institute for Plant \& Food Limited for providing the experimental site, and Shane Maley for managing the experiment and agronomic advice.

\section{REFERENCES}

Anwar, M.R.; McKenzie, B.A.; Hill, G.D. 2003. Phenology and growth response to irrigation and sowing date of Kabuli chickpea (Cicer arietinum L.) in cool- temperate sub humid climate. Journal of Agricultural Science 141: 273-284.

Fletcher, A.L.; Moot, D.J.; Stone, P.J. 2008. Solar radiation interception and canopy expansion of sweet corn in response to phosphorus. European Journal of Agronomy 29: 80-87.

Gallagher, J.N.; Robson, A.N. 1984. Fitting growth sigmoidal curves using maximum likelihood program (MLP) - An Interim Guide. Canterbury, Lincoln University. 12 pp.

Grant, C.A.; Flaten, D.N.; Tomasiewicz, D.J.; Sheppard, S.C. 2000. The importance of early season phosphorus nutrition. Canadian Journal of Plant Science 81: 211-224.

Hay, K.M.; Porter, J.R. 2006. Interception of solar radiation by crop canopy. pp. 35-71. In: The physiology of crop yield. Blackwell Publishing, Oxford.

Lewis, A.H. 1941. The placement of fertilisers. 1. Root crops. Journal of Agricultural Science 31: 295-307.

Lynch, J.; Lauchli, A.; Epstein, E. 1991. Vegetative growth of the common bean in response to phosphorus nutrition. Crop Science 31: 380-387. 
McLaren, R.G.; Cameron, K.C. 1996. Soil science: sustainable production and environmental protection. Oxford University Press, Melbourne. 304 pp.

Moot, D.J.; Matthew, C.; Kemp, P.D. 2007. Growth of pasture and supplementary crops. Pasture and supplements for grazing animals. New Zealand Society of Animal Production. Occasional Publication Number 14: 13-22.

Plenet, D.; Etchebest, S.; Mollier, A.; Pellerin, S. 2000. Growth analysis of maize field crops under phosphorus deficiency. 1. Leaf growth. Plant and Soil 223: 117-130.

Rodriguez, D.; Zubillaga, M.M.; Ploschuk, E.L.; Keltijens, W.G.; Goudriaan, J.; Lavado, R.S. 1998. Plant leaf area expansion and assimilate production in sunflower (Helianthus annuus L.) grown under low phosphorus conditions. Plant and Soil 200: 133-147.

Ross, G.J.S.; Hawkins, D.; Jones, R.D.; Kempton, R.A.; Lausker, F.B.; Payne, R.W.; White, R.P. 1987. Maximum Likelihood Programme. Harpenden, UK. Rothamstead Experimental Station.

Salmon, R.W.; Dumbleton, A.J. 2006. The effect of seed treatment and depth of sowing on forage brassica crop establishment in non-tillage situation. Proceedings of the New Zealand Grassland Association 68: 211-214.
Webb, T.H.; Claydon, J.J.; Harris, S.R. 2000. Quantifying variability of soil physical properties within soil series to address modern land-use issues on the Canterbury Plains, New Zealand. Australian Journal of Soil Research 38: 1115-1129.

White, J.G.H.; Matthew, C.; Kemp, P.D. 1999. Supplementary feeding systems. pp. 175-198. In: New Zealand pasture and crop science. Oxford University Press, Auckland.

Wilson, D.R.; Reid, J.B.; Zyskowski, R.F.; Maley, S.; Pearson, A.J.; Armstrong, S.D.; Catto, W.D.; Stafford, A.D. 2006. Forecasting fertiliser requirements of forage brassica crops. Proceedings of the New Zealand Grassland Association 68: 205-210.

Yunusa, I.A.M.; Siddique, K.H.M.; Belford, R.K.; Karimi, M.M. 1993. Effects of canopy structure on efficiency of radiation interception and use in spring wheat cultivars during the pre-anthesis period in a Mediterranean-type climate. Field Crop Research 35: 113-122. 